\title{
A tough travesía: Mobility constraints among late Holocene Patagonian hunter-gatherers through oxygen stable isotopes in enamel and water sources
}

\author{
Alejandro Serna ${ }^{\mathrm{a}, *}$, Domingo C. Salazar-García ${ }^{\mathrm{b}, \mathrm{c}, \mathrm{d}}$, Luciano O. Valenzuela ${ }^{\mathrm{e}}$, Luciano Prates ${ }^{\mathrm{a}}$ \\ ${ }^{a}$ CONICET - División Arqueología, Facultad de Ciencias Naturales y Museo, Universidad Nacional de La Plata. Anexo Museo, Av. 122 y 60 (1900), La Plata, Argentina \\ ${ }^{\mathrm{b}}$ Grupo de Investigación en Prehistoria IT-1223-19 (UPV-EHU)/IKERBASQUE-Basque Foundation for Science, Vitoria, Spain \\ ${ }^{\mathrm{c}}$ Departament de Prehistòria, Arqueologia i Història Antiga, Universitat de València, València, Spain \\ ${ }^{\mathrm{d}}$ Department of Geological Sciences, University of Cape Town, Cape Town, South Africa \\ e CONICET, Laboratorio de Ecología Evolutiva Humana (LEEH), Núcleo de Estudios Interdisciplinarios Sobre Poblaciones Humanas de Patagonia Austral (NEIPHPA), \\ Unidad de Enseñanza Universitaria Quequén, Facultad de Ciencias Sociales, Universidad del Centro de la Provincia de Buenos Aires, Argentina
}

\section{A R T I C L E I N F O}

\section{Keywords:}

Paleomobility

Stable oxygen isotopes

Hunter-gatherers

Patagonia

\begin{abstract}
A B S T R A C T
Central-eastern North Patagonia is characterized by a severe environmental fragmentation due to the scarce and heterogeneous distribution of fresh water. The main local wet zones, the Negro and Colorado river valleys in the North and the Somuncurá Foothills in the South are separated by a large and harsh dry land, the travesía. In this paper, we assess the effects of this environmental fragmentation in the mobility of the Late Holocene huntergatherers through the analysis of the stable isotopes of oxygen in both enamel and water sources. We analyzed the $\delta^{18} \mathrm{O}$ of the enamel carbonate of 64 human teeth from 42 individuals from the Negro River valley $(n=30)$ and the Somuncurá Foothills $(n=12)$ and transformed them into drinking water values $\left(\delta^{18} \mathrm{O}_{\mathrm{dw}}\right)$ to be compared with an oxygen water baseline built from the most important surface water sources of the area. Our results show variable mobility, but they also highlight two trends regarding the direction of the movement. First, people buried at the Negro River valley seem to have consumed more regularly water from the Colorado River in the North than from other water sources located farther south (e.g. Somuncurá Foothills). Second, the $\delta^{18} \mathrm{O}_{\mathrm{dw}}$ values from the Somuncurá sample show east-to-west prevalent mobility along the foothills, far from the northern water sources (e.g. Colorado River). This weak connectivity between the northern and the southern parts of the study area (Negro and Colorado river valleys and Somuncurá Foothills) is probably related to the harsh environmental constraints imposed by the travesía. Our isotopic results in conjunction with the available archaeological and ethnohistorical data indicate that this large dry land acted as a marginal space in terms of human exploitation and that it certainly influenced human mobility.
\end{abstract}

\section{Introduction}

The way that people moved across the landscape in the past has been deeply discussed in archaeology. Mobility itself has been considered as an adaptive strategy (Binford, 1978; Kelly, 1983; Veth et al., 2008), as a resource in extreme environments (Tafuri et al., 2006), and as an indispensable mechanism for social reproduction and social change (Kelly, 1983; Binford, 1990; Eckardt, 2010; Cabana and Clark, 2011). Paleomobility studies allow archaeologists to understand complex political processes in highly stratified societies (Knudson et al., 2014; Tung and Knudson, 2011), as well as to assess interaction processes on smaller-scale ones (Cameron, 2013). In order to address these issues, it is necessary to take into account the geographic and environmental contexts in which human groups are immersed since they might strongly influence the dynamics of a given population. For instance, some arid environments certainly act as geographic barriers, such as the Sahara Desert (Nikita et al., 2012), constraining human circulation across the landscapes (see also Veth, 1993; Berón, 2016).

This paper focuses on the mobility of the Late Holocene huntergatherers from central-eastern North Patagonia, an area where specific constraints for human use have been observed during the 18th and 19th centuries, but which have not been evaluated in depth for pre-Hispanic times. From a geographical and archaeological view, the study area connects North Patagonia with Dry Pampas and the Atlantic coast with

\footnotetext{
* Corresponding author.

E-mail address: aserna@fcnym.unlp.edu.ar (A. Serna).
} 


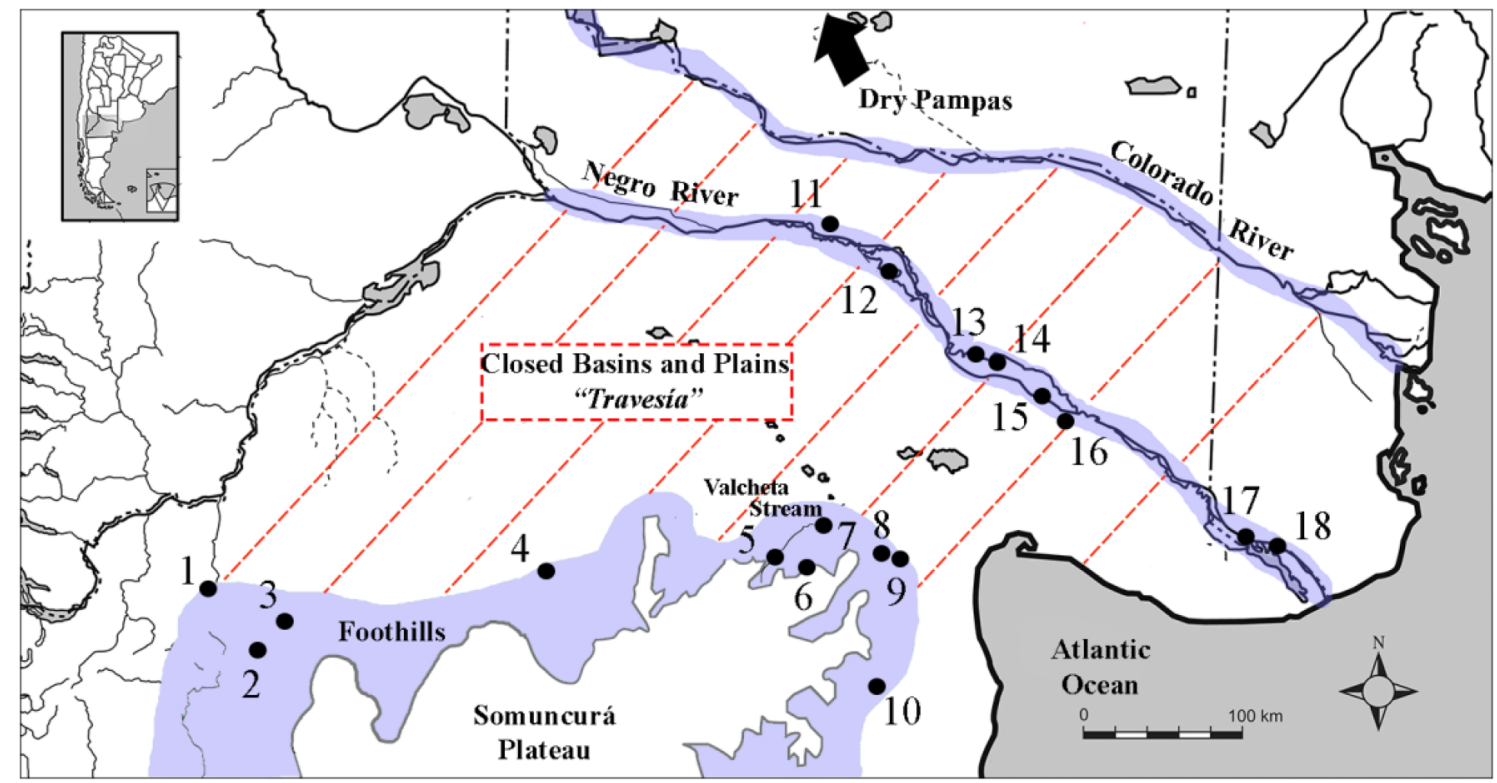

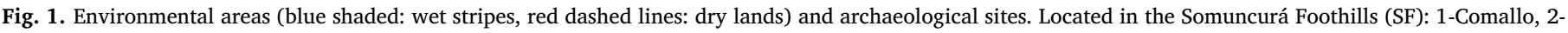

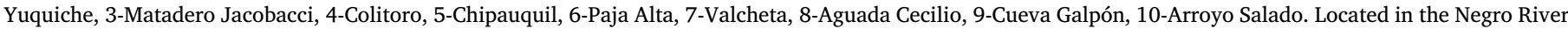

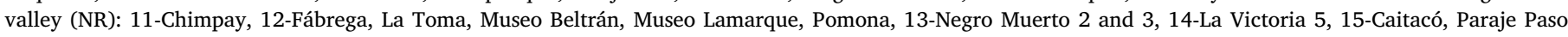
Piedras, 16-Loma de los Muertos, 17-San Javier, 18-Laguna del Juncal.

Western Patagonia (Fig. 1). This region has been characterized by an environmental fragmentation produced by large "dry lands" with quite few non-permanent water sources interrupted by a few "wet stripes" -zones with higher availability of water and environmental productivity- (Prates and Mange, 2016; Serna et al., 2019). These wet stripes are represented by the Colorado and Negro river valleys, and by the Somuncurá Foothills, being the latter separated from the Negro River by a large dry land - > 70,000 $\mathrm{km}^{2}$ - called the Closed Basins and Plains or "travesía" (Fig. 1) (de la Vaulx, 1901; Casamiquela, 1985; Prates and Mange, 2016). Although the travesía was usually crossed by Patagonian hunter-gatherers during historical times, it has been considered as one of the most hostile and feared landscapes in Patagonia (Casamiquela, 1985, Deodat, 1958-1959, among others). During the 19th century, the explorer George C. Musters observed that: "The region is very feared by travelers, and now that I have crossed it I believe certain stories that circulate about people who have perished on that journey; it would be very difficult to find the path again if it were to be lost, while the lack of water in summer, and the danger of horses going astray [...] are both probable risks." ([1869-1870] 1997: 321). To get across the travesía people used special routes (e.g. Chancho and Gualicho routes) only viable for a discrete period of time after the rains (Deodat, 1958-1959; Musters, [1869-1870] 1997). Based on the archaeological record, Prates and Mange (2016) have posed that some springs associated with those routes could have been used as logistic bases for the exploitation of resources and/or as mandatory rest stops to cross the area.

Given the location and size of the travesía, this paper seeks to assess its potential impact in terms of circulation constraints over the Late Holocene hunter-gatherers. We infer the direction of human movement through a drinking water approach based on the comparison between $\delta^{18} \mathrm{O}$ isotopic values of water and human enamel from archaeological sites located on the two wet stripes separated by the travesía: Negro River valley (NR) and the Somuncurá Foothills (SF) (Fig. 1).

\subsection{Oxygen stable isotopes, water and mobility}

One important application of stable isotopes of oxygen $\left({ }^{18} \mathrm{O} /{ }^{16} \mathrm{O}\right)$ in archaeology is tracing human movement because the isotopic values of biogenic tissues are correlated with those from the water sources, which in turn vary geographically. Bioapatite phosphate $\left(\mathrm{PO}_{4}\right)$ and structural carbonate $\left(\mathrm{CO}_{3}\right)$ that form biomineralized tissues, precipitate at constant body temperature in mammals $\left(\sim 37^{\circ} \mathrm{C}\right)$ and differs by a constant isotopic value from the composition of body water (i.e. blood) (Longinelli, 1984; Luz et al., 1984). Although the pool of oxygen isotopes inside the body is the result from a complex process that involves several inputs/outputs, as well as species-specific factors such as body size (Bryant and Froelich, 1995; Kohn, 1996; O'Grady et al., 2012), the main contributor to the isotopic signal is the drinking water (Daux et al., 2008; Podlesak et al., 2008). The oxygen isotopic composition of biological apatite in mammals, therefore, will be directly related to the drinking water isotope values (Longinelli, 1984; Luz et al., 1984).

For past societies that did not have the technology to access to deepwater reservoirs, the environmental drinking water depended on the availability of surface sources, which may have similar oxygen isotope values to those of local precipitation. Isotope values in precipitation follow certain patterns at global scale (Bowen and Revenaugh, 2003), due to a series of meteorological and physical factors known as "Dansgaard́s effects", which include latitude, distance from the coast and elevation, among others (Yurtsever and Gat, 1981; Rozanski et al., 1993). During the hydrologic cycle, the alternation between evaporation and condensation/precipitation generates isotopic fractionation, through the progressive ${ }^{18} \mathrm{O}$-depletion of rainwater as the air mass moves farther from the coast (Clark and Fritz, 1997). Although regionally distinct patterns may arise and can be used to evaluate human mobility in the past, post-precipitation processes (e.g. evaporation) and/or water transport (e.g. a large river carrying water from a highelevation catchment area to a location near from the coast) are capable to generate isotopic differences between the local precipitation and the surface water sources in a given location (Kendall and Coplen, 2001; Darling, 2004). Therefore, using a baseline built on water sources available to consumption is advisable to assess mobility (Knudson, 2009; Serna et al., 2019).

The study area presents an overall elevation gradient with the higher heights in the southwest ( 1000 m.a.s.l.) decreasing northeast, as well as, variation in the amount of rainfall depending on the location with $\sim 400 \mathrm{~mm} / \mathrm{y}$ near the foothills and $<200 \mathrm{~mm} / \mathrm{y}$ eastward (Paruelo et al., 1998; Schäbitz, 2003). As we mentioned, the most important water sources are separated from each other by several $\mathrm{km}$ and some minor sources are hundreds of $\mathrm{km}$ away from the coast (Prates 
Journal of Archaeological Science: Reports

https://www.sciencedirect.com/science/article/pii/S2352409X20302753?dgcid=author

Request to the author: aserna@fcnym.unlp.edu.ar 